\title{
Carbon monoxide-bound hemoglobin vesicles ameliorate multiorgan injuries induced by severe acute pancreatitis in mice by their anti-inflammatory and antioxidant properties
}

\author{
This article was published in the following Dove Press journal: \\ International Journal of Nanomedicine \\ 27 October 2016 \\ Number of times this article has been viewed
}

\author{
Saori Nagao ${ }^{1,2}$ \\ Kazuaki Taguchi ${ }^{3}$ \\ Hiromi Sakai ${ }^{4}$ \\ Keishi Yamasaki ${ }^{3,5}$ \\ Hiroshi Watanabe ${ }^{1,6}$ \\ Masaki Otagiri, ${ }^{3,5}$ \\ Toru Maruyama ${ }^{1,6}$ \\ 'Department of Biopharmaceutics, \\ Graduate School of Pharmaceutical \\ Sciences, Kumamoto University, \\ Kumamoto, ${ }^{2}$ Research Fellow of Japan \\ Society for the Promotion of Science, \\ Tokyo, ${ }^{3}$ Faculty of Pharmaceutical \\ Sciences, Sojo University, Kumamoto, \\ ${ }^{4}$ Department of Chemistry, Nara \\ Medical University, Kashihara, \\ ${ }^{5}$ DDS Research Institute, Sojo \\ University, ${ }^{6}$ Center for Clinical \\ Pharmaceutical Sciences, School \\ of Pharmacy, Kumamoto University, \\ Kumamoto, Japan
}

\begin{abstract}
Carbon monoxide (CO) has attracted attention as a possible therapeutic agent for affecting anti-inflammatory and antioxidant activities. Previously, CO-bound hemoglobin vesicle $(\mathrm{CO}-\mathrm{HbV})$ was developed as a nanotechnology-based $\mathrm{CO}$ donor, and its safety profile and therapeutic potential as a clinically applicable carrier of $\mathrm{CO}$ were examined in vitro and in vivo. In the present study, the therapeutic efficacy of $\mathrm{CO}-\mathrm{HbV}$ against severe acute pancreatitis was examined with secondary distal organ-injured model mice that were fed with a choline-deficient ethionine-supplemented diet. A CO-HbV treatment significantly reduced the mortality of the acute pancreatitis model mice compared to saline and $\mathrm{HbV}$. Biochemical and histological evaluations clearly showed that $\mathrm{CO}-\mathrm{HbV}$ suppressed acute pancreatitis by inhibiting the production of systemic proinflammatory cytokines, neutrophil infiltration, and oxidative injuries in pancreatic tissue. Interestingly, $\mathrm{CO}-\mathrm{HbV}$ also diminished the subsequent damage to distal organs including liver, kidneys, and lungs. This could be due to the suppression of neutrophil infiltration into tissues and the subsequently enhanced oxidative injuries. In contrast, $\mathrm{O}_{2}$-bound $\mathrm{HbV}$, the inactive form of $\mathrm{CO}-\mathrm{HbV}$, was ineffective against both pancreatitis and distal organ injuries, confirming that $\mathrm{CO}$ was directly responsible for the protective effects of $\mathrm{CO}-\mathrm{HbV}$ in acute pancreatitis. These findings suggest that $\mathrm{CO}-\mathrm{HbV}$ has anti-inflammatory and antioxidant characteristics of $\mathrm{CO}$ and consequently exerts a superior protective effect against acute pancreatitis-induced multiorgan damage.
\end{abstract}

Keywords: acute pancreatitis, carbon monoxide, CDE diet, liposome, oxidative stress, inflammation

\section{Introduction}

Acute pancreatitis is a severe acute inflammatory disorder of the pancreas characterized by edema, acinar cell necrosis, and hemorrhage. ${ }^{1}$ Although mild acute pancreatitis is not life-threatening, moderate-to-severe cases can lead to a rate of high mortality. Gabexate mesylate (GM), a protease inhibitor, is clinically used in some countries to treat acute pancreatitis based on evidence indicating that autodigestion by activated pancreatic enzymes is the initial event of acute pancreatitis..$^{2-4}$ On the other hand, some governments, including the Food and Drug Administration (FDA), have not approved or recommended its clinical use ${ }^{5,6}$ because several clinical studies have shown that 1) the degree of hyperenzymemia is not a reliable predictor of the severity and final outcome of the disease and 2) GM has little or no benefit in case of acute pancreatitis patients. $^{7-9}$ In addition to the release of digestive enzymes into the pancreatic 
interstitium, the production of inflammatory cytokines and their release are also associated with the progression of severe acute pancreatitis. ${ }^{10}$

According to the revised Atlanta classification system, damage occurs typically in multiple distal organs including the liver, lungs, and kidneys after the development of severe acute pancreatitis. Although the exact mechanisms responsible for this are not fully understood, an accumulating body of evidence suggests that inflammatory cytokines and oxidative stress play a critical role in the onset and progression of this complication in acute pancreatitis. ${ }^{11,12}$ These systemic responses, which are generally referred to as the systemic inflammatory response syndrome (SIRS), lead to the development of more severe diseases such as multiple organ dysfunction syndrome (MODS), multiple organ failure (MOF), and finally death. In fact, patients who develop persistent distal organ failure within the first few days of the disease are at an increased risk of death, and the mortality has been reported to be as high as 36\%-50\%. ${ }^{13-15}$ These findings suggest that an agent that combines both anti-inflammatory and antioxidative actions would be expected to rescue patients with both severe acute pancreatitis and secondary distal organ injuries.

Emerging evidence indicates that carbon monoxide ( $\mathrm{CO})$, a by-product of inducible heme oxygenase-1, can effectively regulate inflammation and oxidative stress. ${ }^{16-18}$ In fact, recent studies on the use of $\mathrm{CO}$ inhalation or CO-releasing molecules (CORMs) showed that exogenous CO may well serve as a possible clinically viable medical agent for the treatment of inflammation- and oxidative stress-related disorders. By using advanced nanotechnology, recently, CO-bound hemoglobin vesicles $(\mathrm{CO}-\mathrm{HbV})$, in which a concentrated CO-bound hemoglobin $(\mathrm{Hb})$ solution is encapsulated in a phospholipid bilayer membrane (liposome), were developed as a new type of $\mathrm{CO}$ donor. ${ }^{19} \mathrm{CO}-\mathrm{HbV}$ can function as a $\mathrm{CO}$ releasing molecule as a $\mathrm{CO}$ donor, and it also functions as an oxygen carrier after releasing $\mathrm{CO} .{ }^{20}$ This unique property of $\mathrm{HbV}$ as a dual-gas carrier promises to prevent $\mathrm{CO}$-induced respiratory failure. In fact, previously, the safety characteristics of $\mathrm{CO}-\mathrm{HbV}$ were reported: no effect on hemodynamics and respiratory function, a high biocompatibility, a low toxicity, and a good metabolic performance. ${ }^{21}$ Moreover, $\mathrm{CO}-\mathrm{HbV}$ was reported to have therapeutic potential for retarding the onset or progression of idiopathic pulmonary fibrosis and inflammatory bowel disease by its anti-inflammatory and antioxidative activities. ${ }^{19,21}$ These findings lead us to hypothesize that $\mathrm{CO}-\mathrm{HbV}$ might be a possible therapeutic agent for the treatment of both acute pancreatitis and secondary multiorgan failures.

The purpose of this study was to evaluate the therapeutic effects of $\mathrm{CO}-\mathrm{HbV}$ on severe acute pancreatitis and its secondary distal organ damage by using a choline-deficient ethionine-supplemented (CDE) diet-induced acute pancreatitis mice model. In addition, whether the anti-inflammatory and antioxidative functions of $\mathrm{CO}$ contribute to the therapeutic effect of $\mathrm{CO}-\mathrm{HbV}$ was also investigated.

\section{Materials and methods Chemicals}

The experiment using human red blood cells to produce $\mathrm{HbV}$ was approved by the ethical committee of Nara Medical University. Outdated donated human red blood cells were provided by the Japanese Red Cross Society (Tokyo, Japan), and human $\mathrm{Hb}$ was purified through pasteurization and nanofiltration as previously reported. ${ }^{22-24}$ The 1,2-dipalmitoylsn-glycero-3-phosphatidylcholine (DPPC), cholesterol, and 1,5-O-dihexadecyl- $N$-succinyl-L-glutamate (DHSG) were purchased from Nippon Fine Chemical Co. Ltd. (Osaka, Japan). 1,2-Distearoyl-sn-glycero-3-phosphatidyl-ethanolamine- $N$ PEG $_{5000}$ (DSPE-PEG) was purchased from NOF Corp. (Tokyo, Japan). All other chemicals were the highest grade commercially available chemicals, and all the solutions were prepared by using deionized water. $\mathrm{O}_{2}$-bound $\mathrm{HbV}$ and $\mathrm{CO}-\mathrm{HbV}$ were prepared according to the previously reported procedures. ${ }^{19}$ The lipid bilayer of both $\mathrm{HbV}$ and $\mathrm{CO}-\mathrm{HbV}$ consisted of DPPC, cholesterol, and DHSG at a molar ratio of 5/4/0.9 and DSPE-PEG of $0.3 \mathrm{~mol} \%$. The average diameters of the $\mathrm{HbV}$ and $\mathrm{CO}-\mathrm{HbV}$ particles used in this study were maintained at $\sim 280 \mathrm{~nm}$. The $\mathrm{HbV}$ and $\mathrm{CO}-\mathrm{HbV}$ suspended in a physiological salt solution were at $[\mathrm{Hb}]=10 \mathrm{~g} / \mathrm{dL}$ and [lipid] $=9.0 \mathrm{~g} / \mathrm{dL}$. The carboxyl $\mathrm{Hb}$ rate in $\mathrm{CO}-\mathrm{HbV}$ was $\sim 100 \%$, whereas that in $\mathrm{O}_{2}$-bound $\mathrm{HbV}$ was $<5 \%$.

\section{Production of CDE diet-induced acute pancreatitis mice}

Maintenance of the mice and the experimental procedures performed on them were carried out in accordance with the National Institute of Health guidelines. All the animal experiments were reviewed and approved by the Animal Care and Use Committee of Kumamoto University (permit no: A 27-003) and Sojo University (permit no: 2014-P-018). Female BALB/cN mice (aged 5 weeks) were purchased from Kyudo Co., Ltd. (Saga, Japan). All the mice were housed in a room kept at $18^{\circ} \mathrm{C}-24^{\circ} \mathrm{C}$ and $40 \%-70 \%$ relative humidity, with a 12-h light/dark cycle, and allowed free access to food and drinking water. After a 24-h period of fasting, the mice were fed a CDE diet (MP Biomedicals, Solon, OH, USA; catalogue no: 960214) for 3 days (for the analysis of therapeutic efficacies) or for 5 days (for the 14-day mortality rate). Saline, $\mathrm{HbV}$ (1,000 $\mathrm{mg} \mathrm{Hb} / \mathrm{kg}$ ), and 
$\mathrm{CO}-\mathrm{HbV}(1,000 \mathrm{mg} \mathrm{Hb} / \mathrm{kg})$ were administered via tail vein at 1 day after the beginning of CDE treatment. The mice were fed a standard rodent diet CE-2 (CLEA Japan, Inc., Tokyo, Japan) outside of the CDE diet period.

\section{Plasma biochemical parameters}

Blood samples were collected from the inferior vena cava at 3 days after the start of the CDE treatment. The blood samples were centrifuged $(3,000 \mathrm{~g} ; 10 \mathrm{~min})$ and subsequently ultracentrifuged to remove $\mathrm{HbV}(50,000 \mathrm{~g} ; 30 \mathrm{~min})$ in order to obtain plasma samples for the analysis of plasma biochemical parameters and cytokine levels. All the plasma biochemical parameters (amylase, lipase, aspartate transaminase [AST], alanine transaminase [ALT], and blood urea nitrogen [BUN]) were analyzed by using Fuji DRI-CHEM 7000Z and DRI-CHEM slides (Fujifilm, Tokyo, Japan).

\section{Histological and immunohistochemical analyses}

After blood collection, organs (pancreas, liver, kidneys, and lung) harvested for a histological and immunohistochemical study. The organs were fixed in 10\% phosphate-buffered formalin and were embedded in paraffin. The prepared tissues were cut into $4-\mu \mathrm{m}$-thick sections. Hematoxylin and eosin (HE) staining for morphological analysis and immunostaining for nitrotyrosine $\left(\mathrm{NO}_{2}\right.$-Tyr) and myeloperoxidase (MPO) were performed as previously described. ${ }^{25}$ The primary antibodies containing $\mathrm{NO}_{2}$-Tyr (Millipore, Tokyo, Japan; catalogue no: AB5411) and MPO (Santa Cruz, CA, USA; catalogue no: sc-16128-R) were diluted 50-fold prior to use. The secondary antibodies for $\mathrm{NO}_{2}-\mathrm{Tyr}$ and $\mathrm{MPO}$ were Alexa Fluor 546 goat anti-rabbit IgG $(\mathrm{H}+\mathrm{L})\left(1: 200\right.$; Invitrogen ${ }^{\mathrm{TM}}$, Eugene, OR, USA; catalogue no: AB11010). Cells were also treated with 4',6-diamidino-2-phenylindole (DAPI; Dojin Chemical, Kumamoto, Japan). After the reaction, the slides were observed by using a microscope (Keyence Corp., BZ-8000, Osaka, Japan).

\section{Quantification of tumor necrosis factor (TNF)- $\alpha$ and interleukin- I $\beta$ (IL-I $\beta$ )}

The amounts of TNF- $\alpha$ and IL- $1 \beta$ in the plasma sample were determined by using an enzyme-linked immunosorbent assay kit (Biolegend, San Diego, CA, USA) following the manufacturer's instructions.

\section{Measurement of the lung wet-to-dry ratio}

One leaf of the left lung, which was used for the calculation of wet-to-dry ratio, was placed in a microtube, weighed, dried at $80^{\circ} \mathrm{C}$ for $48 \mathrm{~h}$, and weighed again. The wet lung was divided by value for the mass of the dry lung, representing the wet-dry lung ratio and indicating the fraction of the wet lung weight comprised of water.

\section{Statistics}

All data were expressed as the mean \pm standard deviation. Statistical analyses for multiple comparisons in the study were determined by analysis of variance (one-way or twoway) followed by the Bonferroni analysis. For survival studies, log-rank test was used. A $P$-value $<0.05$ was considered significant.

\section{Results}

\section{Therapeutic potential of $\mathrm{CO}-\mathrm{HbV}$ on CDE diet-induced acute pancreatitis}

Feeding mice a CDE diet is a well-established method for producing a model for severe pancreatitis with a high mortality. ${ }^{26,27}$ In the present study, after feeding the mice the $\mathrm{CDE}$ diet, they were given saline, $\mathrm{HbV}$, or $\mathrm{CO}-\mathrm{HbV}$ administration via the tail vein at $24 \mathrm{~h}$ after the start of CDE feeding, and survival was monitored for the first 14 days. As shown in Figure 1, 100\% (10/10) of the saline-treated mice and $90 \%(9 / 10)$ of the $\mathrm{HbV}$-treated mice died within 7 days, whereas the 14-day mortality of the $\mathrm{CO}-\mathrm{HbV}$-treated mice was $50 \%(5 / 10)$. This survival rate for the CO-HbV-treated mice was significantly higher than the corresponding values for both the saline- and $\mathrm{HbV}$-treated mice $(P<0.05)$. Remarkable increases in serum amylase and lipase levels were noted in the saline-treated mice and the $\mathrm{HbV}$-treated mice 3 days

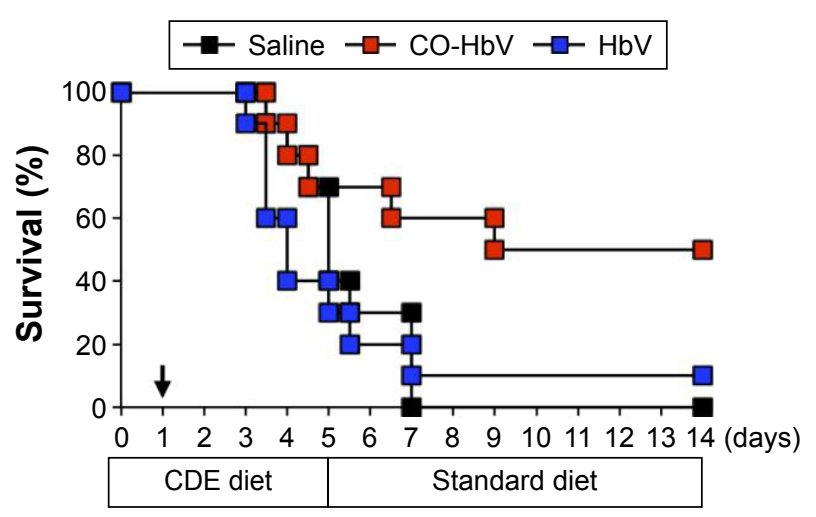

Figure I Effect of saline, $\mathrm{HbV}$, and CO-HbV administration on mortality in CDE diet-induced acute pancreatitis mice.

Notes: Survival rates were monitored for 14 days after the start of the CDE diet. Saline, $\mathrm{HbV}(\mathrm{I}, 000 \mathrm{mg} \mathrm{Hb} / \mathrm{kg})$, and CO-HbV $(\mathrm{I}, 000 \mathrm{mg} \mathrm{Hb} / \mathrm{kg})$ were administered via the tail vein at I day after the start of the CDE diet (arrow). The number of mice $(n)$ in all group was I0. $P=0.044$, saline versus $C O-H b V . P=0.035, \mathrm{HbV}$ versus $\mathrm{CO}-\mathrm{HbV}$.

Abbreviations: $\mathrm{CDE}$, choline-deficient ethionine-supplemented; $\mathrm{CO}-\mathrm{HbV}$, carbon monoxide-bound hemoglobin vesicle. 
after the start of feeding the CDE diet (Figure 2A). However, the $\mathrm{CO}-\mathrm{HbV}$ treatment significantly attenuated the levels of these pancreatic enzymes (Figure 2A). The protective effect of $\mathrm{CO}-\mathrm{HbV}$ on pancreatitis was also confirmed by the histological examination of pancreas sections stained by $\mathrm{HE}$ in each group (Figure 2B). Although the interstitium of the CDE-fed saline-treated mice and $\mathrm{HbV}$-treated mice is edematous, the changes were greatly reduced in the CDEfed mice that were treated with $\mathrm{CO}-\mathrm{HbV}$. A large number of inflammatory cells infiltrated to the interstitium of the saline- and $\mathrm{HbV}$-treated mice, but few inflammatory cells infiltrated to the interstitium of the $\mathrm{CO}-\mathrm{HbV}$-treated mice. Similarly, diffuse necrotic changes were found in the salineand $\mathrm{HbV}$-treated groups but scarcely found in the $\mathrm{CO}-\mathrm{HbV}$ treated mice. These results suggest that $\mathrm{CO}-\mathrm{HbV}$ is effective against acute pancreatitis and that the release of $\mathrm{CO}$ from the $\mathrm{CO}-\mathrm{HbV}$ is responsible for its actions.

\section{Effect of CO-HbV on inflammation and oxidative stress in pancreatic tissues}

Neutrophil infiltration is a hallmark of inflammation, and evidence has accumulated to indicate that neutrophils play a key role in the induction of acute pancreatitis. ${ }^{28}$ Therefore, immunostaining of MPO, an enzyme that is present at relatively high levels in neutrophil granulocytes, was performed to evaluate neutrophil infiltration in the pancreatic tissues in the CDE diet-induced acute pancreatitis mice model for each sample treatment. As shown in Figure 3A, the accumulation of MPO in pancreatic tissues of the acute pancreatitis mice that were treated with saline and $\mathrm{HbV}$ was much higher than that in the control mice, whereas the $\mathrm{CO}-\mathrm{HbV}$ treatment markedly reduced the accumulation of MPO.

As neutrophils that release toxic substances, such as reactive oxygen species (ROS), cause tissue injury in the inflamed pancreas, ${ }^{29}$ pancreatic tissues were subjected to immunostaining for $\mathrm{NO}_{2}$-Tyr, an oxidation product derived from proteins. $\mathrm{NO}_{2}$-Tyr was observed to have accumulated in the CDE-fed mice treated with saline and $\mathrm{HbV}$, whereas the $\mathrm{CO}-\mathrm{HbV}$ treatment suppressed the level of this oxidative stress marker (Figure 3B).

\section{Effect of CO-HbV on systemic inflammation in CDE diet-induced acute pancreatitis}

A CDE diet induces not only localized pancreatic damage but also distal organ injury associated with a systemic inflammatory response. Thus, the effect of $\mathrm{CO}-\mathrm{HbV}$ on systemic inflammation was assessed by measuring proinflammatory
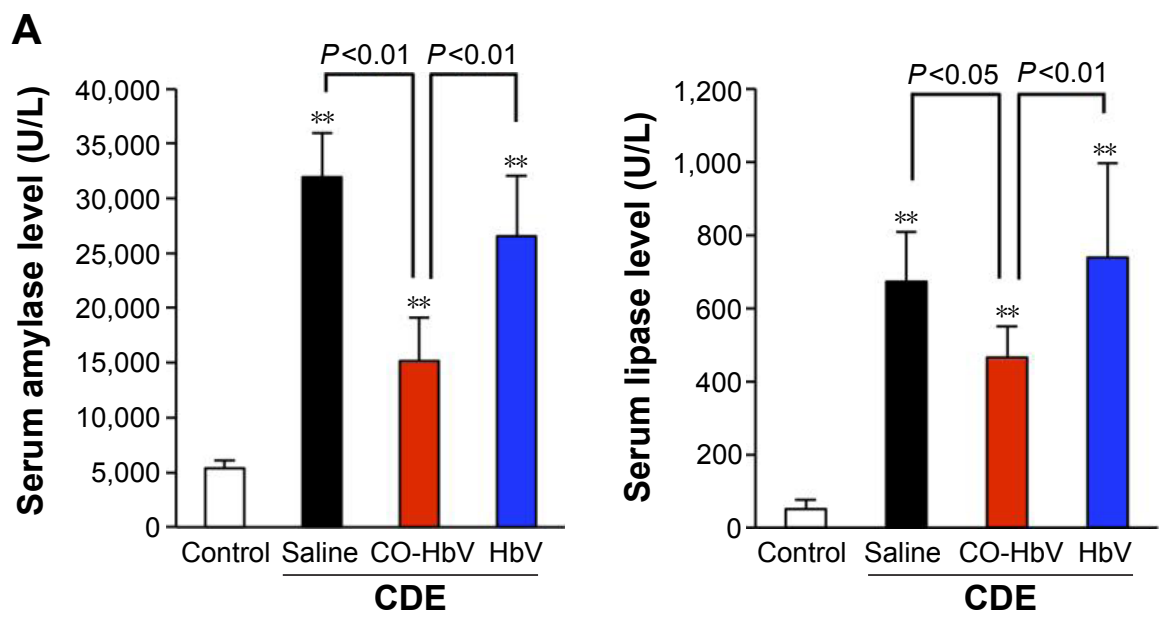

B

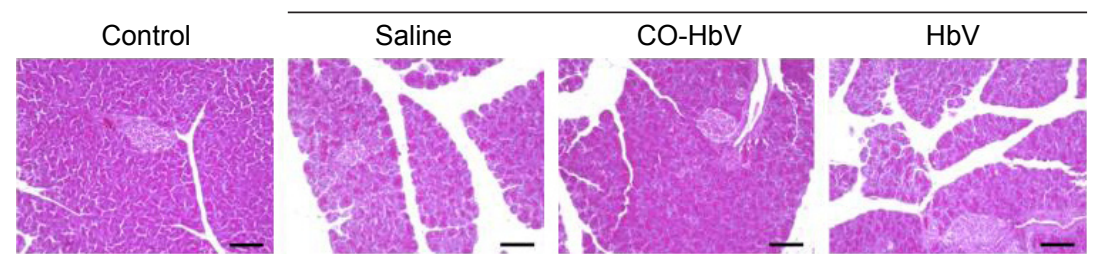

Figure 2 Evaluation of therapeutic effects after the administration of saline, $\mathrm{HbV}$, and CO-HbV to CDE diet-induced acute pancreatitis mice. Notes: (A) Serum amylase and lipase levels at 3 days after the start of the $C D E$ diet. Each value represents the mean \pm standard deviation ( $n=6$ ). $* * P<0.0$ I versus control. (B) Representative HE-stained pancreatic sections. Scale bars represent $100 \mu \mathrm{m}$.

Abbreviations: $\mathrm{CDE}$, choline-deficient ethionine-supplemented; $\mathrm{CO}-\mathrm{HbV}$, carbon monoxide-bound hemoglobin vesicle; HE, hematoxylin and eosin. 
A
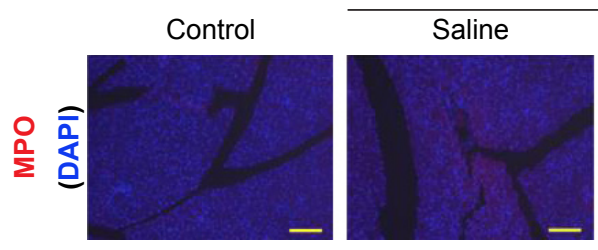

CDE

B
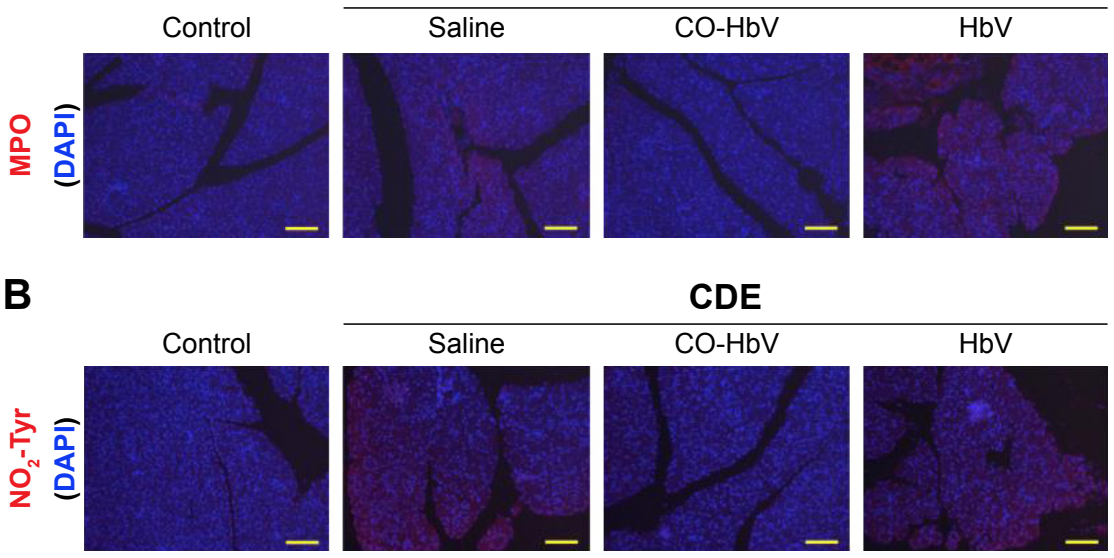

CDE

\section{$\mathrm{CO}-\mathrm{HbV}$}
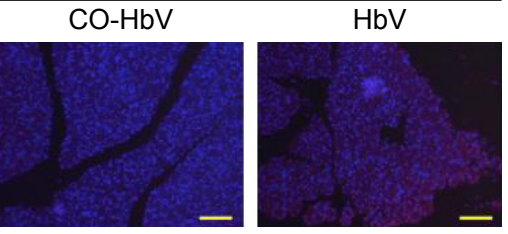

Figure 3 Immunological staining of pancreatic sections in CDE diet-induced acute pancreatitis mice.

Notes: (A) Neutrophil infiltration was evaluated by immunostaining of MPO (red) in the pancreatic slices at 3 days after the start of the CDE diet; (B) immunostaining of pancreatic sections for the oxidative stress markers of amino acid, $\mathrm{NO}_{2}$-Tyr (red), at 3 days after the start of the CDE diet. DAPI (blue) was used to counterstain the nuclei. Scale bars represent $100 \mu \mathrm{m}$.

Abbreviations: CDE, choline-deficient ethionine-supplemented; CO-HbV, carbon monoxide-bound hemoglobin vesicle; DAPI, 4',6-diamidino-2-phenylindole; MPO, myeloperoxidase; $\mathrm{NO}_{2}$-Tyr, nitrotyrosine.

cytokine levels in the circulation. As a result, the $\mathrm{CO}-\mathrm{HbV}$ treatment significantly decreased the levels of serum proinflammatory cytokines, TNF- $\alpha$ and IL-1 $\beta$ (Figure 4).

\section{Therapeutic potential of CO-HbV on distal organ injury in CDE diet-induced acute pancreatitis}

In order to investigate the effect of $\mathrm{CO}-\mathrm{HbV}$ on distal organ injury in the CDE diet-induced acute pancreatitis mice, the liver, kidneys, and lungs as distal organs were focused because injuries to these organs are frequently found in patients with severe acute pancreatitis. The values of AST and
ALT, which reflect hepatic injury, were found to be higher in the saline- and $\mathrm{HbV}$-treated mice than the corresponding values in the $\mathrm{CO}-\mathrm{HbV}$-treated mice (Figure 5A). Livers obtained from the saline- and $\mathrm{HbV}$-treated mice exhibited extensive hepatic necrosis (Figure 5B). Furthermore, immunostaining the liver sections for MPO and $\mathrm{NO}_{2}$-Tyr showed that the $\mathrm{CO}-\mathrm{HbV}$ treatment suppressed the accumulation of MPO and subsequent oxidative injury in the liver compared to the saline and $\mathrm{HbV}$ treatments (Figure 5C and $\mathrm{D}$ ).

In the kidneys, it was observed that the $\mathrm{CO}-\mathrm{HbV}$ treatment attenuated the extent of renal injury in CDE-fed mice based on the results of serum BUN levels (Figure 6A)
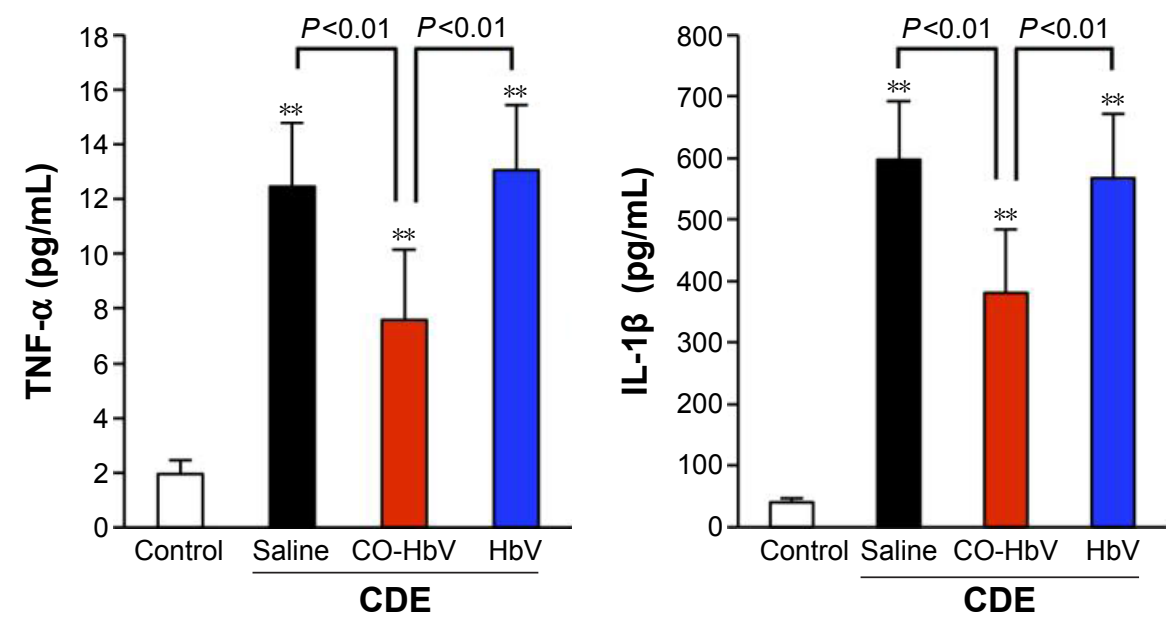

Figure 4 Effect of saline, $\mathrm{HbV}$, and CO-HbV administration on systemic inflammation in CDE diet-induced acute pancreatitis mice.

Notes: The levels of cytokines (TNF- $\alpha$ and IL-I $\beta$ ) in serum at 3 days after the start of the CDE diet were measured by means of an ELISA kit. Each value represents the mean \pm standard deviation $(n=6)$. $* * p<0.0$ I versus control.

Abbreviations: $\mathrm{CDE}$, choline-deficient ethionine-supplemented; CO-HbV, carbon monoxide-bound hemoglobin vesicle; ELISA, enzyme-linked immunosorbent assay; TNF- $\alpha$, tumor necrosis factor- $\alpha$. 

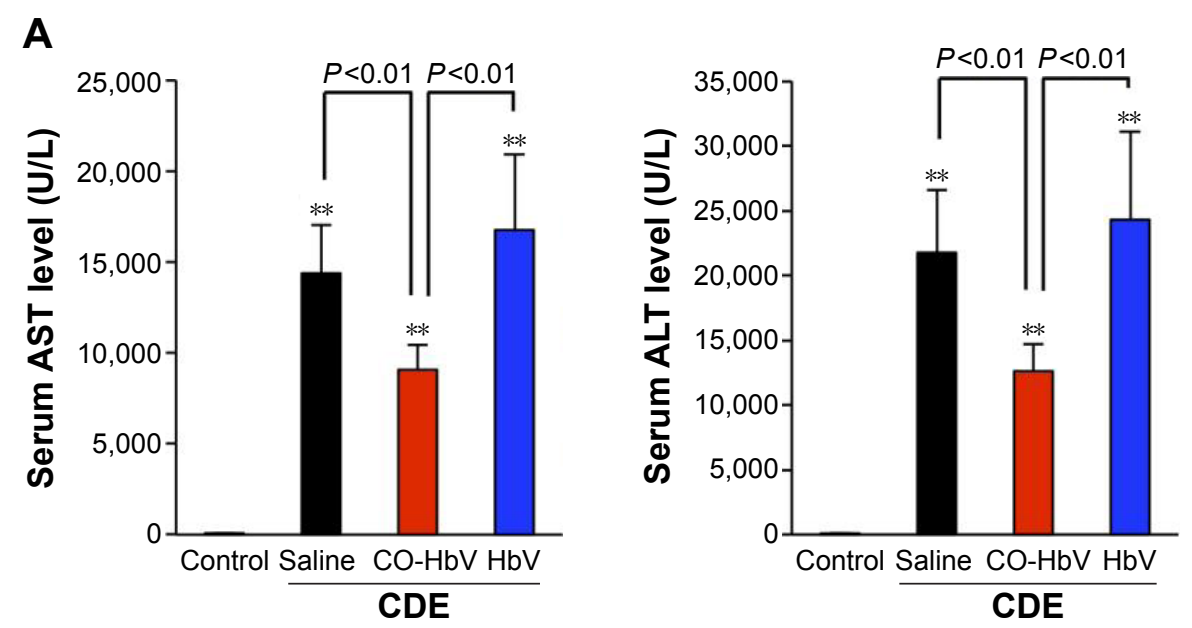

B

\section{CDE}
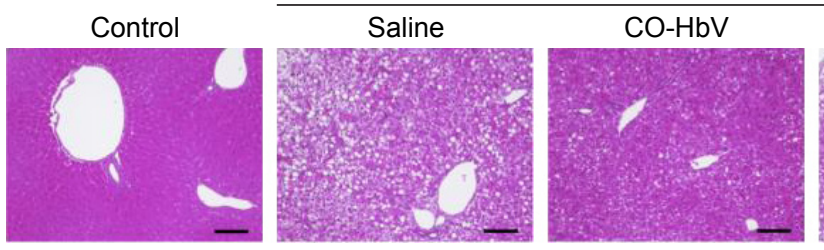

$\mathrm{HbV}$

C
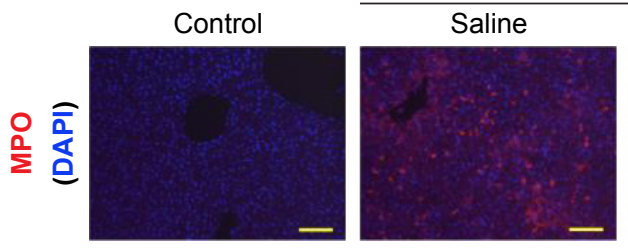

CDE

D
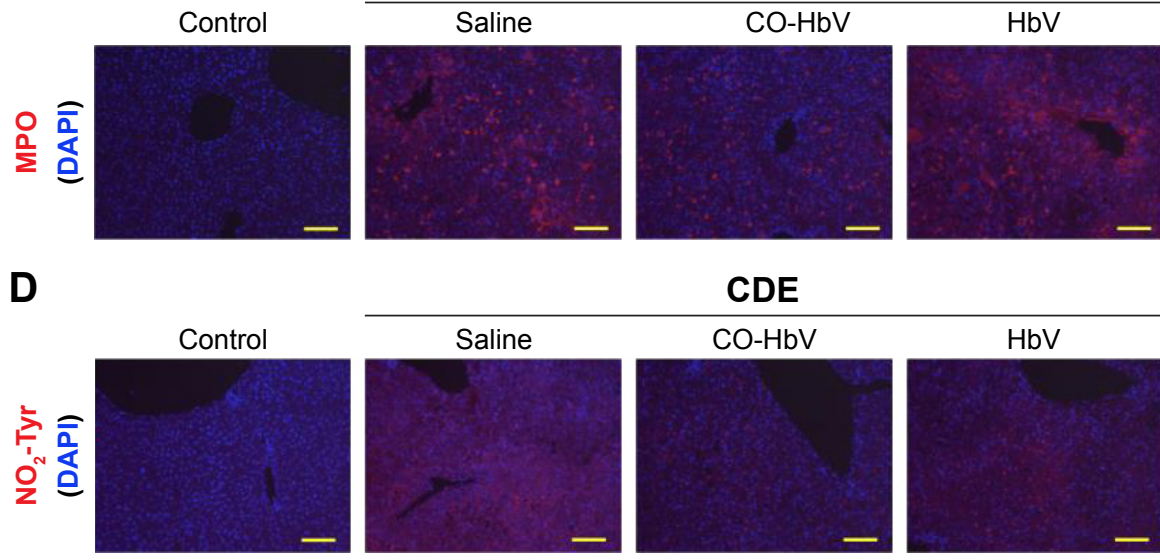

CDE
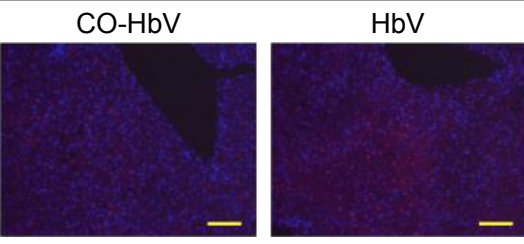

Figure 5 Evaluation of hepatic injury and immunological staining of liver sections after the administration of saline, $\mathrm{HbV}$, and CO-HbV to CDE diet-induced acute pancreatitis mice. Notes: (A) Serum AST and ALT levels and (B) representative HE-stained liver sections at 3 days after the start of the CDE diet. Each value represents the mean \pm standard deviation $(\mathrm{n}=6)$. ${ }^{* * P}<0.0$ I versus control. Immunostaining of (C) MPO (red) and (D) $\mathrm{NO}_{2}-\mathrm{Tyr}$ (red) in the liver slices was performed at 3 days after beginning of $\mathrm{CDE}$ diet. DAPI (blue) was used to counterstain the nuclei. Scale bars represent $100 \mu \mathrm{m}$.

Abbreviations: ALT, alanine transaminase; AST, aspartate transaminase; CDE, choline-deficient ethionine-supplemented; CO-HbV, carbon monoxide-bound hemoglobin vesicle; DAPI, 4',6-diamidino-2-phenylindole; $\mathrm{HE}$, hematoxylin and eosin; MPO, myeloperoxidase; $\mathrm{NO}_{2}$-Tyr, nitrotyrosine.

and histological evaluations (Figure 6B). In the lungs, the wet-to-dry ratio, which reflects edema, in the $\mathrm{CO}-\mathrm{HbV}$-treated mice was significantly lower than that in saline- and $\mathrm{HbV}$ treated mice (Figure 7A). In addition, HE staining of lung sections exhibited alveolar membrane thickening in both the saline- and $\mathrm{HbV}$-treated mice, but it was suppressed in $\mathrm{CO}$ $\mathrm{HbV}$-treated mice (Figure 7B). Similar to the immunostaining of liver sections, as shown in Figure $5 \mathrm{C}$ and $\mathrm{D}$, the $\mathrm{CO}-\mathrm{HbV}$ treatment clearly suppressed the accumulation of MPO and $\mathrm{NO}_{2}$-Tyr in the kidneys and lungs compared to the saline and $\mathrm{HbV}$ treatments (Figures 6C and D and 7C and D).

\section{Discussion}

Acute pancreatitis is one of the most frequent gastrointestinal diseases, and mild cases require 2- to 5-day hospital stays. In more severe cases, such as the development of complications including MOF, hospitalization can be prolonged considerably, with a much cost. ${ }^{30}$ Although worldwide guidelines have been established for managing acute pancreatitis, including rehydration, early nutrition, acceptable analgesia, oxygenation, and the use of antibiotics, when infections are confirmed, ${ }^{31-34}$ there is no recommended drug protocol for preventing the progression of pancreatitis itself. Therefore, 
A

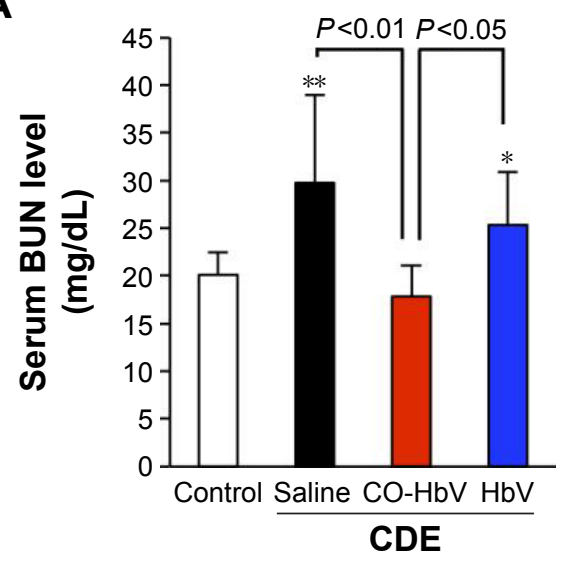

B

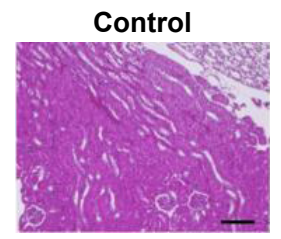

CDE + CO-HbV
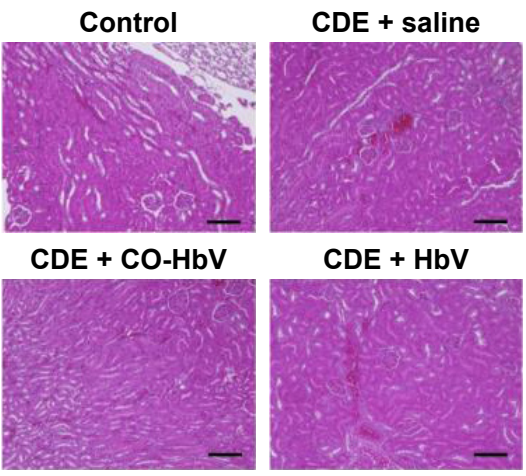

$\mathrm{CDE}+\mathrm{HbV}$

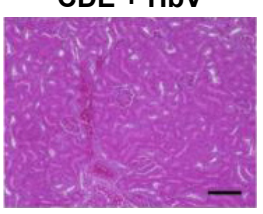

C

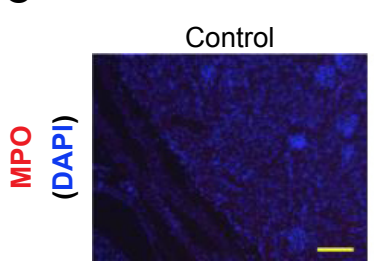

D

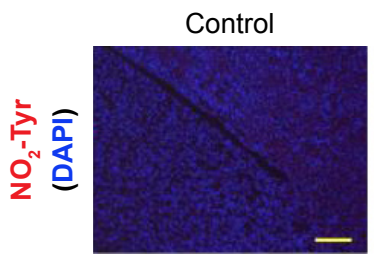

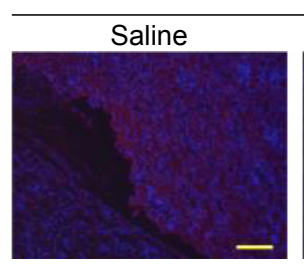
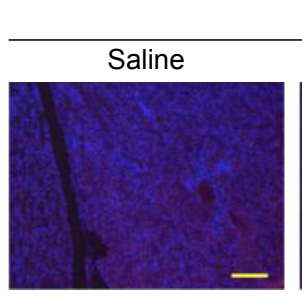

CDE

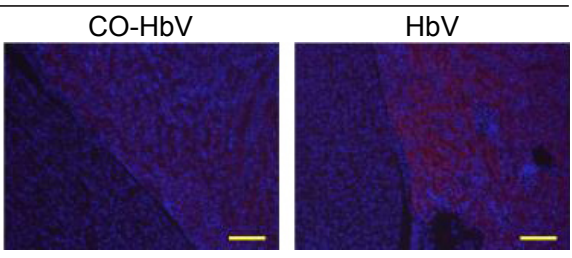

CDE

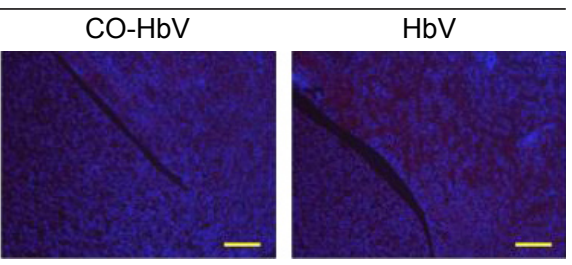

Figure 6 Evaluation of renal injury and immunological staining of kidney sections after the administration of saline, $\mathrm{HbV}$, and CO-HbV to CDE diet-induced acute pancreatitis mice.

Notes: (A) Serum BUN levels and (B) representative HE-stained kidney sections at 3 days after the start of the CDE diet. Each value represents the mean \pm standard deviation $(n=6)$. ${ }^{*} * P<0.01$ versus control. ${ }^{*} P<0.05$ versus control. Immunostaining of (C) MPO (red) and (D) $\mathrm{NO}_{2}$-Tyr (red) in the kidney slices was performed at 3 days after the start of the CDE diet. DAPI (blue) was used to counterstain the nuclei. Scale bars represent $100 \mu \mathrm{m}$.

Abbreviations: BUN, blood urea nitrogen; CDE, choline-deficient ethionine-supplemented; CO-HbV, carbon monoxide-bound hemoglobin vesicle; DAPI, 4',6-diamidino2-phenylindole; $\mathrm{HE}$, hematoxylin and eosin; MPO, myeloperoxidase; $\mathrm{NO}_{2}$-Tyr, nitrotyrosine.

developing safe and effective therapeutics that are able to protect both the pancreas and distal organs under conditions of severe pancreatitis would be highly desirable. The findings reported in the present study strongly indicate that $\mathrm{CO}-\mathrm{HbV}$ significantly improves the survival rate of mice with $\mathrm{CDE}$ diet-induced acute pancreatitis through the reduction of severe acute pancreatitis and by reducing the extent of secondary distal organ injuries (Figures 1 and 2). Clinical studies have clarified that a severe condition of acute pancreatitis is associated with a mortality reaching $30 \%$, even when the recommended medical and surgical therapies are performed. ${ }^{34}$ Based on the present findings, it appears that $\mathrm{CO}-\mathrm{HbV}$ represents a novel and effective therapeutic strategy for reducing severe pancreatitis in patients and subsequently improves their mortality.

It is well known that ROS play an essential role in the progression of acute pancreatitis ${ }^{35-37}$ because it directly interacts with biological molecules in the body and impairs their function. Although ROS are produced by multiple pathways in pathological conditions, neutrophils are important ROS generators and are responsible for local tissue damage. ${ }^{38}$ Cunha et al previously reported that a $\mathrm{CO}$ donor (dimanganese decacarbonyl) inhibited the adhesion and migration of the neutrophils during the inflammatory response. ${ }^{39,40}$ In this study, it was found that the administration of $\mathrm{CO}-\mathrm{HbV}$ attenuated MPO accumulation, which is frequently used to estimate the extent of accumulation of tissue neutrophils in inflamed tissue, ${ }^{41,42}$ in pancreatic tissue under conditions of severe acute pancreatitis (Figure 3A). Furthermore, corresponding to MPO accumulation, $\mathrm{CO}-\mathrm{HbV}$ efficiently inhibited the accumulation of $\mathrm{NO}_{2}-$ Tyr, a marker of oxidative stress for proteins (Figure 3B). Thus, it appears that $\mathrm{CO}-\mathrm{HbV}$ inhibits the infiltration of neutrophils and subsequent ROS injuries in pancreatic tissue, resulting in the suppression for the progression of acute pancreatitis.

Proinflammatory cytokines, such as TNF- $\alpha$ and IL-1 $\beta$, are mainly produced and released during severe acute pancreatitis and are thought to significantly contribute to 
A

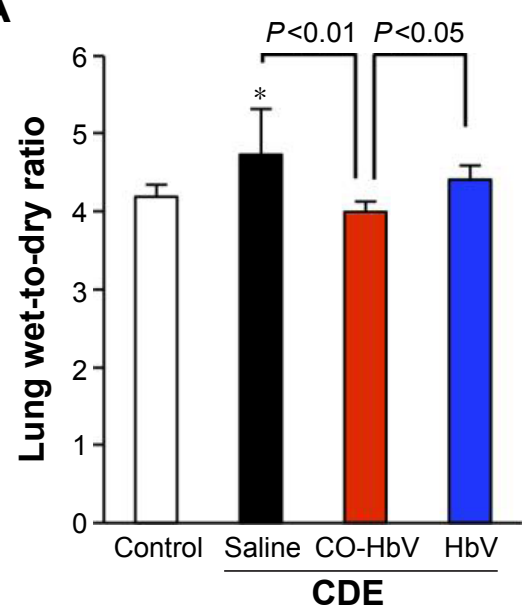

C

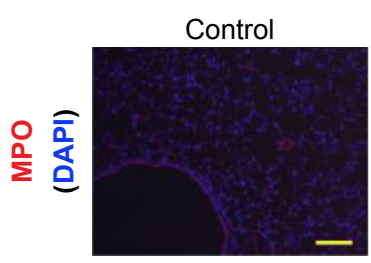

D

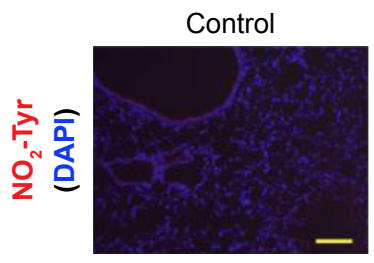

B

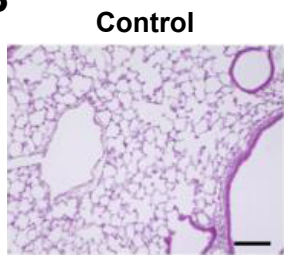

$\mathrm{CDE}+\mathrm{CO}-\mathrm{HbV}$
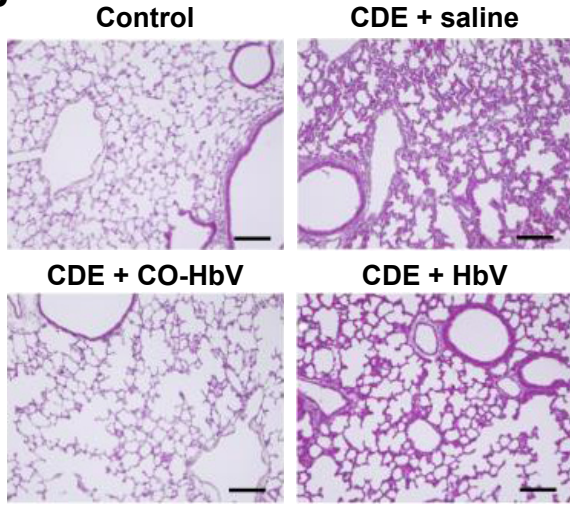

$\mathrm{CDE}+\mathrm{HbV}$

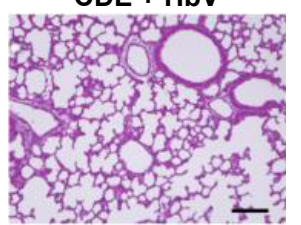

CDE

CO-HbV

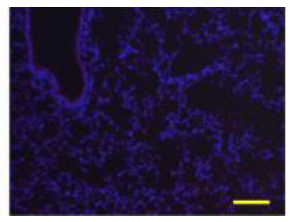

CDE
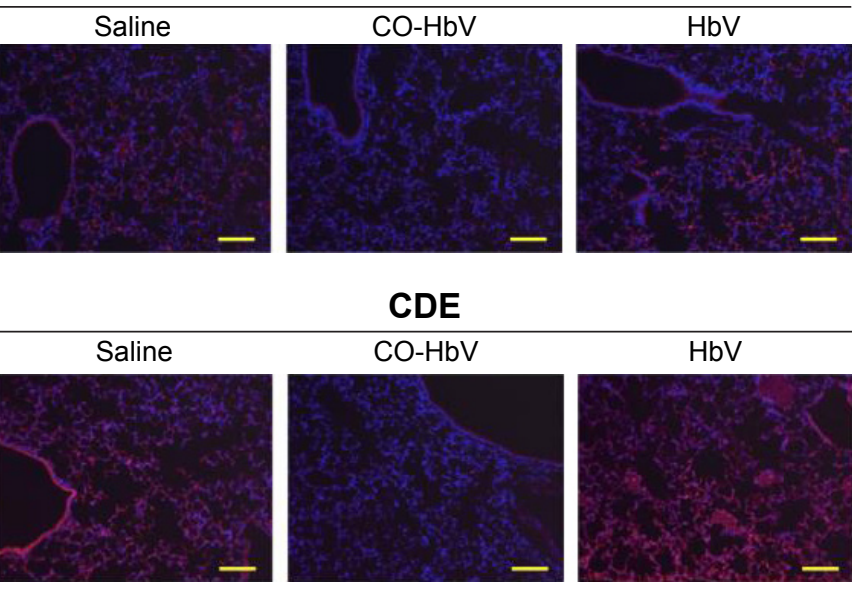

CO-HbV
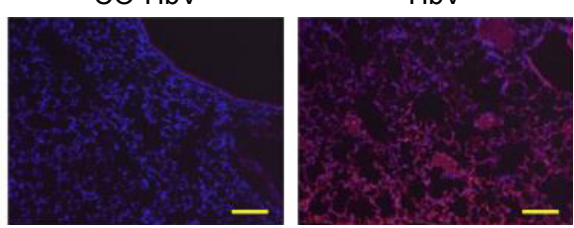

Figure 7 Evaluation of lung injury and immunological staining of lung sections after the administration of saline, HbV, and CO-HbV to CDE diet-induced acute pancreatitis mice.

Notes: (A) Lung wet-to-dry ratio and (B) representative HE-stained lung sections at 3 days after the start of the CDE diet. Each value represents the mean \pm standard deviation ( $n=6$ ). $* P<0.05$ versus control. Immunostaining of (C) MPO (red) and (D) NO -Tyr (red) in the lung slices was performed at 3 days after the start of the CDE diet. DAPI (blue) was used to counterstain the nuclei. Scale bars represent $100 \mu \mathrm{m}$.

Abbreviations: $\mathrm{CDE}$, choline-deficient ethionine-supplemented; $\mathrm{CO}-\mathrm{HbV}$, carbon monoxide-bound hemoglobin vesicle; DAPI, 4',6-diamidino-2-phenylindole; $\mathrm{HE}$, hematoxylin and eosin; MPO, myeloperoxidase; $\mathrm{NO}_{2}$-Tyr, nitrotyrosine.

the onset and progression of pancreatitis. ${ }^{43,44}$ For example, a marked attenuation of the severity of acute pancreatitis is observed when receptors for TNF- $\alpha$ and IL- $1 \beta$ are blocked, and the mortality is dramatically reduced in TNF- $\alpha$ and IL-1 $\beta$ knockout mice after the development of severe acute pancreatitis. ${ }^{45-47}$ Moreover, anti-cytokine therapies against TNF- $\alpha$ and IL- $1 \beta$ showed protective effects in experimental animal models with severe acute pancreatitis. ${ }^{48}$ Since the serum levels of TNF- $\alpha$ and IL- $1 \beta$ during the course of severe acute pancreatitis were decreased by a $\mathrm{CO}-\mathrm{HbV}$ treatment (Figure 4), the therapeutic effect of $\mathrm{CO}-\mathrm{HbV}$ could be modulated by the production of systemic cytokines.

In order to emphasize this, $\mathrm{CO}-\mathrm{HbV}$ was found to comprehensively ameliorate not only pancreatic injury but also secondary distal organ damage, including liver, kidneys, and lungs in the present acute pancreatitis model. This implies that $\mathrm{CO}-\mathrm{HbV}$ could suppress the SIRS and MODS that accompany severe acute pancreatitis (Figures 5-7). Disease-related systemic responses, such as SIRS, are mediated by different inflammatory cytokines that are released during the course of primary organ injury. In particular, TNF- $\alpha$ and IL- $1 \beta$ play a pivotal role in the development of the SIRS and the subsequent distal organ failures in cases of severe acute pancreatitis. ${ }^{44}$ In the present study, $\mathrm{CO}-\mathrm{HbV}$ was found to effectively inhibit TNF- $\alpha$ and IL- $1 \beta$ production in the circulation (Figure 4 ). In addition, neutrophils are also considered to play an important role in the onset and development of secondary distal organ damage in various diseases. ${ }^{49-51}$ As described previously, the infiltration of neutrophils into tissues causes substantial oxidative injury to distal organs. Similar to the pancreas, $\mathrm{CO}-\mathrm{HbV}$ suppressed neutrophil infiltration and subsequent ROS injuries in the liver, kidneys, and lungs of CDE mice (Figures 5-7) as judged by immunostaining for MPO and $\mathrm{NO}_{2}$-Tyr. These findings indicate that both the anti-inflammatory and antioxidative 
activities of $\mathrm{CO}-\mathrm{HbV}$ not only play an important role in its protective effects against acute pancreatitis but also mediate multiple distal organ injuries.

In the present study, it was determined that $\mathrm{CO}$ directly contributed to the therapeutic effects of $\mathrm{CO}-\mathrm{HbV}$ on both acute pancreatitis and its complications because $\mathrm{HbV}$ that was loaded with oxygen was ineffective. This indicates that $\mathrm{HbV}$ has the capacity to carry and release $\mathrm{CO}$ in vivo. Accumulating evidence has confirmed the safety and usefulness of $\mathrm{HbV}$ as an oxygen carrier such as its biological compatibility, ${ }^{22}$ the absence of toxicity, ${ }^{23}$ no accumulation in the body, ${ }^{52,53}$ and ability to transport oxygen. ${ }^{54,55}$ These beneficial properties of $\mathrm{HbV}$ can be retained, even in the form of $\mathrm{CO}-\mathrm{HbV} .{ }^{21}$ Moreover, $\mathrm{HbV}$ has been reported to have a good retention in the blood circulation of cynomolgus monkeys, ${ }^{56}$ and the half-life of $\mathrm{HbV}$ in humans was estimated to be $\sim 3-4$ days. ${ }^{57}$ Consequently, $\mathrm{HbV}$ is a promising, safe gas carrier for both $\mathrm{CO}$ and oxygen with long-acting properties. For the clinical application of $\mathrm{CO}-\mathrm{HbV}$, the characterization of $\mathrm{CO}$ release from $\mathrm{CO}-\mathrm{HbV}$ is an important issue. Thus, further investigation regarding this pharmacokinetic study will be necessary to develop a comprehensive understanding of the effect of $\mathrm{CO}-\mathrm{HbV}$ on acute pancreatitis.

\section{Conclusion}

The findings of the present study show that 1) $\mathrm{CO}-\mathrm{HbV}$ can significantly decrease mortality and prevent both pancreatic damage and severe complications (multiple organ injuries) via the anti-inflammatory and antioxidant activities of $\mathrm{CO}$ and that 2) $\mathrm{CO}-\mathrm{HbV}$ functions as a $\mathrm{CO}$ donor, suggesting that $\mathrm{CO}-\mathrm{HbV}$ could be a promising nanotechnology-based $\mathrm{CO}$ donor and has the potential for use as a therapy not only for acute pancreatitis but also for a wide range of ROS and inflammation-related diseases.

\section{Acknowledgments}

This work was supported, in part, by Health Sciences Research Grants from the Ministry of Health, Labour and Welfare of Japan (H24-SOUYAKUSOUGOU-IPPAN-009), by a Grant-in-Aid for Young Scientist (B) from the Japan Society for the Promotion of Science (JSPS; KAKENHI 26860121), and by JSPS KAKENHI Grant Number JP15J009957.

\section{Disclosure}

Hiromi Sakai holds patents related to the production and utilization of $\mathrm{Hb}$ vesicles. The other authors report no conflicts of interest in this work.

\section{References}

1. Steinberg W, Tenner S. Acute pancreatitis. N Engl J Med. 1994;330(17): $1198-1210$.
2. Geokas MC, Van Lancker JL, Kadell BM, Machleder HI. Acute pancreatitis. Ann Intern Med. 1972;76(1):105-117.

3. Becker V. Pathological anatomy and pathogenesis of acute pancreatitis. World J Surg. 1981;5(3):303-313.

4. Trapnell JE. Pathophysiology of acute pancreatitis. World J Surg. 1981; 5(3):319-327.

5. Banks PA, Freeman ML; Practice Parameters Committee of the American College of Gastroenterology. Practice guidelines in acute pancreatitis. Am J Gastroenterol. 2006;101(10):2379-2400.

6. Whitcomb DC. Clinical practice. Acute pancreatitis. NEngl J Med. 2006; 354(20):2142-2150

7. Büchler M, Malfertheiner P, Uhl W, et al. Gabexate mesilate in human acute pancreatitis. German Pancreatitis Study Group. Gastroenterology. 1993;104(4):1165-1170.

8. Valderrama R, Pérez-Mateo M, Navarro S, et al. Multicenter doubleblind trial of gabexate mesylate (FOY) in unselected patients with acute pancreatitis. Digestion. 1992;51(2):65-70.

9. Yang CY, Chang-Chien CS, Liaw YF. Controlled trial of protease inhibitor gabexelate mesilate (FOY) in the treatment of acute pancreatitis. Pancreas. 1987;2(6):698-700.

10. Frossard JL, Steer ML, Pastor CM. Acute pancreatitis. Lancet. 2008; 371(9607):143-152.

11. Saluja AK, Steer ML. Pathophysiology of pancreatitis. Role of cytokines and other mediators of inflammation. Digestion. 1999;60(Suppl 1): $27-33$.

12. Bhatia M, Wong FL, Cao Y, et al. Pathophysiology of acute pancreatitis. Pancreatology. 2005;5(2-3):132-144.

13. Johnson CD, Abu-Hilal M. Persistent organ failure during the first week as a marker of fatal outcome in acute pancreatitis. Gut. 2004;53(9): $1340-1344$.

14. Mofidi R, Duff MD, Wigmore SJ, Madhavan KK, Garden OJ, Parks RW. Association between early systemic inflammatory response, severity of multiorgan dysfunction and death in acute pancreatitis. Br J Surg. 2006;93(6):738-744.

15. Buter A, Imrie CW, Carter CR, Evans S, McKay CJ. Dynamic nature of early organ dysfunction determines outcome in acute pancreatitis. Br J Surg. 2002;89(3):298-302.

16. Otterbein LE, Bach FH, Alam J, et al. Carbon monoxide has antiinflammatory effects involving the mitogen-activated protein kinase pathway. Nat Med. 2000;6(4):422-428.

17. Zuckerbraun BS, Chin BY, Bilban M, et al. Carbon monoxide signals via inhibition of cytochrome $c$ oxidase and generation of mitochondrial reactive oxygen species. FASEB J. 2007;21(4):1099-1106.

18. Motterlini R, Otterbein LE. The therapeutic potential of carbon monoxide. Nat Rev Drug Discov. 2010;9(9):728-743.

19. Nagao S, Taguchi K, Sakai H, et al. Carbon monoxide-bound hemoglobinvesicles for the treatment of bleomycin-induced pulmonary fibrosis. Biomaterials. 2014;35(24):6553-6562.

20. Sakai H, Horinouchi H, Tsuchida E, Kobayashi K. Hemoglobin vesicles and red blood cells as carriers of carbon monoxide prior to oxygen for resuscitation after hemorrhagic shock in a rat model. Shock. 2009;31(5):507-514.

21. Nagao S, Taguchi K, Miyazaki Y, et al. Evaluation of a new type of nano-sized carbon monoxide donor on treating mice with experimentally induced colitis. J Control Release. 2016;234:49-58.

22. Sakai H, Masada Y, Horinouchi H, et al. Physiological capacity of the reticuloendothelial system for the degradation of hemoglobin vesicles (artificial oxygen carriers) after massive intravenous doses by daily repeated infusions for 14 days. J Pharmacol Exp Ther. 2004;311(3): 874-884.

23. Sakai H, Horinouchi H, Masada Y, et al. Metabolism of hemoglobinvesicles (artificial oxygen carriers) and their influence on organ functions in a rat model. Biomaterials. 2004;25(18):4317-4325.

24. Sakai H, Takeoka S, Park SI, et al. Surface modification of hemoglobin vesicles with poly(ethylene glycol) and effects on aggregation, viscosity, and blood flow during $90 \%$ exchange transfusion in anesthetized rats. Bioconjug Chem. 1997;8(1):23-30. 
25. Taguchi K, Miyasato M, Ujihira H, et al. Hepatically-metabolized and-excreted artificial oxygen carrier, hemoglobin vesicles, can be safely used under conditions of hepatic impairment. Toxicol Appl Pharmacol. 2010;248(3):234-241.

26. Lombardi B, Rao NK. Acute hemorrhagic pancreatic necrosis in mice. Influence of the age and sex of the animals and of dietary ethionine, choline, methionine, and adenine sulfate. Am J Pathol. 1975;81(1): $87-100$.

27. Lombardi B, Estes LW, Longnecker DS. Acute hemorrhagic pancreatitis (massive necrosis) with fat necrosis induced in mice by DLethionine fed with a choline-deficient diet. Am J Pathol. 1975;79(3): 465-480.

28. Gukovskaya AS, Vaquero E, Zaninovic V, et al. Neutrophils and NADPH oxidase mediate intrapancreatic trypsin activation in murine experimental acute pancreatitis. Gastroenterology. 2002;122(4):974-984.

29. van Berlo D, Wessels A, Boots AW, et al. Neutrophil-derived ROS contribute to oxidative DNA damage induction by quartz particles. Free Radic Biol Med. 2010;49(11):1685-1693.

30. Dick JF, Gardner TB, Merrens EJ. Acute pancreatitis: new developments and strategies for the hospitalist. J Hosp Med. Epub 2016 May 31.

31. Greenberg JA, Hsu J, Bawazeer M, et al. Clinical practice guideline: management of acute pancreatitis. Can J Surg. 2016;59(2):128-140.

32. Yokoe M, Takada T, Mayumi T, et al. Japanese guidelines for the management of acute pancreatitis: Japanese Guidelines 2015. J Hepatobiliary Pancreat Sci. 2015;22(6):405-432.

33. Pezzilli R, Zerbi A, Campra D, et al. Consensus guidelines on severe acute pancreatitis. Dig Liver Dis. 2015;47(7):532-543.

34. Working Group IAP/APA Acute Pancreatitis Guidelines. IAP/APA evidence-based guidelines for the management of acute pancreatitis. Pancreatology. 2013;13(4 Suppl 2):e1-e15.

35. Guice KS, Miller DE, Oldham KT, Townsend CM, Thompson JC. Superoxide dismutase and catalase: a possible role in established pancreatitis. Am J Surg. 1986;151(1):163-169.

36. Leung PS, Chan YC. Role of oxidative stress in pancreatic inflammation. Antioxid Redox Signal. 2009;11(1):135-165.

37. Wisner J, Green D, Ferrell L, Renner I. Evidence for a role of oxygen derived free radicals in the pathogenesis of caerulein induced acute pancreatitis in rats. Gut. 1988;29(11):1516-1523.

38. Buckley CD, Ross EA, McGettrick HM, et al. Identification of a phenotypically and functionally distinct population of long-lived neutrophils in a model of reverse endothelial migration. J Leukoc Biol. 2006;79(2):303-311.

39. Dal-Secco D, Freitas A, Abreu MA, et al. Reduction of ICAM-1 expression by carbon monoxide via soluble guanylate cyclase activation accounts for modulation of neutrophil migration. Naunyn Schmiedebergs Arch Pharmacol. 2010;381(6):483-493.

40. Freitas A, Alves-Filho JC, Secco DD, et al. Heme oxygenase/carbon monoxide-biliverdin pathway down regulates neutrophil rolling, adhesion and migration in acute inflammation. Br J Pharmacol. 2006;149(4): $345-354$.
41. Hillegass LM, Griswold DE, Brickson B, Albrightson-Winslow C. Assessment of myeloperoxidase activity in whole rat kidney. J Pharmacol Methods. 1990;24(4):285-295.

42. Sener G, Kabasakal L, Cetinel S, Contuk G, Gedik N, Yeğen BC. Leukotriene receptor blocker montelukast protects against burn-induced oxidative injury of the skin and remote organs. Burns. 2005;31(5):587-596.

43. Kingsnorth A. Role of cytokines and their inhibitors in acute pancreatitis. Gut. 1997;40(1):1-4.

44. Pereda J, Sabater L, Aparisi L, et al. Interaction between cytokines and oxidative stress in acute pancreatitis. Curr Med Chem. 2006;13(23): 2775-2787.

45. Zyromski N, Murr MM. Evolving concepts in the pathophysiology of acute pancreatitis. Surgery. 2003;133(3):235-237.

46. Pastor CM, Matthay MA, Frossard JL. Pancreatitis-associated acute lung injury: new insights. Chest. 2003;124(6):2341-2351.

47. Pastor CM, Frossard JL. Are genetically modified mice useful for the understanding of acute pancreatitis? FASEB J. 2001;15(6):893-897.

48. Masamune A, Shimosegawa T. [Anti-cytokine therapy for severe acute pancreatitis]. Nihon Rinsho. 2004;62(11):2116-2121. Japanese.

49. Wu D, Zeng Y, Fan Y, et al. Reverse-migrated neutrophils regulated by JAM-C are involved in acute pancreatitis-associated lung injury. Sci Rep. 2016;6:20545.

50. Guice KS, Oldham KT, Caty MG, Johnson KJ, Ward PA. Neutrophildependent, oxygen-radical mediated lung injury associated with acute pancreatitis. Ann Surg. 1989;210(6):740-747.

51. Bhatia M, Saluja AK, Hofbauer B, Lee HS, Frossard JL, Steer ML. The effects of neutrophil depletion on a completely noninvasive model of acute pancreatitis-associated lung injury. Int J Pancreatol. 1998; 24(2):77-83.

52. Taguchi K, Urata Y, Anraku M, et al. Pharmacokinetic study of enclosed hemoglobin and outer lipid component after the administration of hemoglobin vesicles as an artificial oxygen carrier. Drug Metab Dispos. 2009;37(7):1456-1463.

53. Taguchi K, Nagao S, Yamasaki K, et al. Biological responsiveness and metabolic performance of liposome-encapsulated hemoglobin (hemoglobin-vesicles) in apolipoprotein E-deficient mice after massive intravenous injection. Biol Pharm Bull. 2015;38(10):1606-1616.

54. Sakai H, Masada Y, Horinouchi H, et al. Hemoglobin-vesicles suspended in recombinant human serum albumin for resuscitation from hemorrhagic shock in anesthetized rats. Crit Care Med. 2004;32(2):539-545.

55. Sakai H, Seishi Y, Obata Y, et al. Fluid resuscitation with artificial oxygen carriers in hemorrhaged rats: profiles of hemoglobin-vesicle degradation and hematopoiesis for 14 days. Shock. 2009;31(2):192-200.

56. Taguchi K, Watanabe H, Sakai H, et al. A fourteen-day observation and pharmacokinetic evaluation after a massive intravenous infusion of hemoglobin-vesicles (artificial oxygen carriers) in cynomolgus monkeys. J Drug Metab Toxicol. 2012;3(4):128.

57. Taguchi K, Maruyama T, Iwao Y, et al. Pharmacokinetics of single and repeated injection of hemoglobin-vesicles in hemorrhagic shock rat model. J Control Release. 2009;136(3):232-239.
International Journal of Nanomedicine

\section{Publish your work in this journal}

The International Journal of Nanomedicine is an international, peerreviewed journal focusing on the application of nanotechnology in diagnostics, therapeutics, and drug delivery systems throughout the biomedical field. This journal is indexed on PubMed Central, MedLine, CAS, SciSearch ${ }^{\circledR}$, Current Contents ${ }^{\circledR} /$ Clinical Medicine,

\section{Dovepress}

Journal Citation Reports/Science Edition, EMBase, Scopus and the Elsevier Bibliographic databases. The manuscript management system is completely online and includes a very quick and fair peer-review system, which is all easy to use. Visit http://www.dovepress.com/ testimonials.php to read real quotes from published authors. 